\title{
Changes in milk urea around insemination are negatively associated with conception success in dairy cows
}

\author{
A. Albaaj, G. Foucras, and D. Raboisson ${ }^{1}$ \\ Université de Toulouse, École Nationale Vétérinaire, Institut National de Recherche Agronomique, \\ Unité 1225 IHAP Interaction Hôtes Agents Pathogènes, 23 Chemin des Capelles, 31076 Toulouse Cedex 3, France
}

\begin{abstract}
Dietary protein levels are a risk factor for poor reproductive performance. Conception is particularly impaired in cases of high blood or milk urea. The objective of this study was to investigate the association between conception and low milk urea or changes in milk urea around artificial insemination (AI). Data were obtained from the French Milk Control Program for a 4-yr period (2009-2012). Milk urea values between 250 and $450 \mathrm{mg} /$ $\mathrm{kg}(4.3$ and $7.7 \mathrm{mM})$ were considered intermediate (I), and values $\leq 150 \mathrm{mg} / \mathrm{kg}(2.6 \mathrm{mM})$ were considered low (L). Milk urea values before and after each AI were allocated into 4 classes representing the dynamics of milk urea (before-after; I-I, I-L, L-I, and L-L). Subclinical ketosis was defined using milk fat and protein contents before AI as proxies. A logistic regression with a Poisson correction and herd as a random variable was then performed on data from Holstein or all breeds of cows. The success of conception was decreased [relative risk $(95 \%$ confidence interval $)=0.96(0.94-0.99)]$ in lowurea cows compared with intermediate-urea cows after AI; no significant association was found for urea levels before AI. When combining data on urea before and after AI, I-L urea cows exhibited a 5 to $9 \%$ decrease in conception compared with I-I urea cows, and L-I urea cows showed no difference in conception success compared with I-I urea cows. A decreased conception success for L-L urea cows compared with I-I urea cows was observed for the analysis with cows of all breeds. This work revealed that a decrease in urea from intermediate (before AI) to low (after AI) is a risk factor for conception failure. Surveys of variation in milk urea in dairy cows close to breeding are highly recommended. Key words: dairy cow, milk urea, conception
\end{abstract}

Received September 30, 2016

Accepted December 19, 2016.

${ }^{1}$ Corresponding author: d.raboisson@envt.fr

\section{INTRODUCTION}

Efficient nutritional management of dairy cattle at calving is one of the most important factors in sustainable dairy farming. It has important effects on the health and reproductive performance of dairy cows. Farmers adopt various nutritional strategies to meet high production requirements while minimizing feed costs and maximizing economic returns. Cows in the early postpartum period experience negative energy balance when their energy requirements exceed their dietary intake (Bauman and Currie, 1980; Bell, 1995). Negative energy balance remains a major challenge for the dairy industry, and extensive literature is available on its physiology, strategic management, and effects on health and performance (Beam and Butler, 1999; Wathes et al., 2003; Raboisson et al., 2014). Protein supply presents a major dietary challenge for postpartum and lactating cows. High-protein diets are widely used during early lactation to stimulate high milk production. However, such diets may be deleterious for reproductive performance, especially when rumendegradable or rumen-undegradable protein exceeds the cow's requirements (Butler, 1998). In contrast, diets with low levels of proteins are often provided to beef cows, which may be fed only hay or grazed on old-stage pastures. Low-protein diets are occasionally used in dairy herds, and the number of herds with continuous low bulk milk urea or high variations in milk urea is increasing (authors' observations).

Urea is the metabolic end product of protein catabolism in the body (Butler, 1998). Blood urea concentration is a sensitive indicator of protein metabolic efficiency (Kenny et al., 2002). As it circulates through the blood, concentrations of urea equilibrate into all body fluids because of its small molecular size and neutral charge. The level of blood urea is highly correlated with that of milk urea, and both can be used to evaluate the nitrogen nutritional status of the animals (Oltner and Wiktorsson, 1983; Baker et al., 1995).

The link between excess dietary protein, particularly $\mathrm{RDP}$, and the fertility of dairy cows has been widely 
studied. Many studies have reported a negative association between high dietary protein levels and reproductive performance (Butler et al., 1996; Chaveiro et al., 2011). Other studies have found that dietary protein level has no effect on fertility or conception, although it is highly correlated with milk and blood urea (Barton et al., 1996; Dawuda et al., 2002; Laven et al., 2004). Cows can adapt to continuous high dietary protein without any decrease in reproductive performance, but an increase in dietary protein is a known risk factor for infertility (Westwood et al., 1998).

Few studies have investigated the association between low dietary protein and reproductive performance. The interval between calving and the first service was found to be longer in herds with urea $<4.5 \mathrm{~m} M$ compared with herds with urea between 4.5 and $5 \mathrm{~m} M$ in one study (Gustafsson and Carlsson, 1993) and in herds with low urea concentration in another study (Carlsson and Pehrson, 1993). Cows with low blood urea $(<2.5$ $\mathrm{m} M$ ) and glucose also had poor fertility (Miettinen, 1991). These results have limited value because these analyses (1) were performed using the mean herd values (Gustafsson and Carlsson, 1993); (2) included low numbers of cows (Miettinen, 1991); and (3) measured urea only once at a fixed date without distinguishing before and after insemination. The only work that has analyzed the effect of changes with respect to the date of AI reported the opposite results, with increased conception success with low $(<4.5 \mathrm{mM})$ and high $(>6.5$ $\mathrm{m} M)$ urea levels before AI compared with moderate urea values (Godden et al., 2001).

The objective of this study was to investigate the association between low milk urea concentrations and conception in dairy cows, with a special focus on the dynamic of urea levels around AI.

\section{MATERIALS AND METHODS}

\section{Data and Variables}

The records from herds enrolled in the Milk Control Program (MCP) in France from 2009 to 2012 (inclusive) were provided by France Livestock Genetics (http://www.francegenetique-elevage.fr/). Records included lactation number, date of calving, all test-day milk results, and lactation data (length and production) for all lactations. The MCP included 61, 57, and $85 \%$ of the herds, cows, and milk produced in France, respectively. The coverage rate of dairy cows included in the MCP varied across dairy production areas (from 40 to $67 \%$ ). Measuring milk urea is optional for farmers enrolled in the MCP and is done on an average of $58 \%$ of test-days. The records for milk urea during the same period were provided by France Conseil Elevage (http://www.france-conseil-elevage.fr/). The French Livestock Institute (http://www.idele.fr/) provided data on AI. These data included the identity of the dams, dates of all AI, and the identity of the sires. Data were collected using MySQL software (version 5.0, Oracle Corp., Redwood City, CA). Milk urea data were gathered from the test-day database. Only AI at DIM $<200$ were included, and milk yield was adjusted to correspond to a reference lactation period of $305 \mathrm{~d}$ (305-d MY).

The final data set contained milk urea and production data from the closest test-days before and after each AI. The periods between the previous test-day and the AI and between the AI and the following testdays were restricted to $<40 \mathrm{~d}$ (Figure 1 ). This limited the exclusion of AI for early and late test-days, in accordance with an average of one test-day per month in France. The average interval between AI and both precedent and subsequent test-day was $17 \mathrm{~d}$. A brief description of the final data set for each year of the study is reported in Table 1.

A proxy of subclinical ketosis (SCK) was constructed using fat and protein contents from the closest test-day before AI. This proxy was defined as fat content $>45$ $\mathrm{mg} / \mathrm{kg}$ and protein content $<28 \mathrm{mg} / \mathrm{kg}$, as previously described (Albaaj et al., 2016). This definition also accounts for the criteria that are generally used in the field and reported in the literature (Duffield et al., 1997; Heuer et al., 2001).

For each AI, conception was considered a binary trait and defined as successful if it was followed by a calving after 265 to $295 \mathrm{~d}$. This duration was defined as the average period of gestation $\pm 15 \mathrm{~d}$, as recommended by the French Livestock Institute (www.idele.fr). Milk urea was first examined as a continuous variable to investigate the shape of its association with conception success. It was then classified as intermediate (I) for values between 250 and $450 \mathrm{mg} / \mathrm{kg}(4.3$ and $7.7 \mathrm{mM}$ ) or low $(\mathbf{L})$ for values $\leq 150 \mathrm{mg} / \mathrm{kg}(2.6 \mathrm{mM})$. These thresholds were defined using a nonparametric model (see Statistical Analysis). They are also in accordance with previous results in this field (Refsdal et al., 1985; Pehrson et al., 1992; Carlsson and Pehrson, 1994). The lower threshold of optimal milk urea concentrations reported in these studies was $4 \mathrm{mM}(233 \mathrm{mg} / \mathrm{kg})$. Another study reported this threshold to be between 175 and $220 \mathrm{mg} / \mathrm{kg}$ (Kirchgessner et al., 1988).

Then, for each AI, cows were categorized according to the dynamic of milk urea levels into 4 classes: cows with intermediate levels before and after AI (I-I; control group), cows with intermediate levels before and low levels after AI (I-L), cows with low levels before and intermediate levels after AI (L-I), and cows with low levels before and low levels after AI (L-L). 


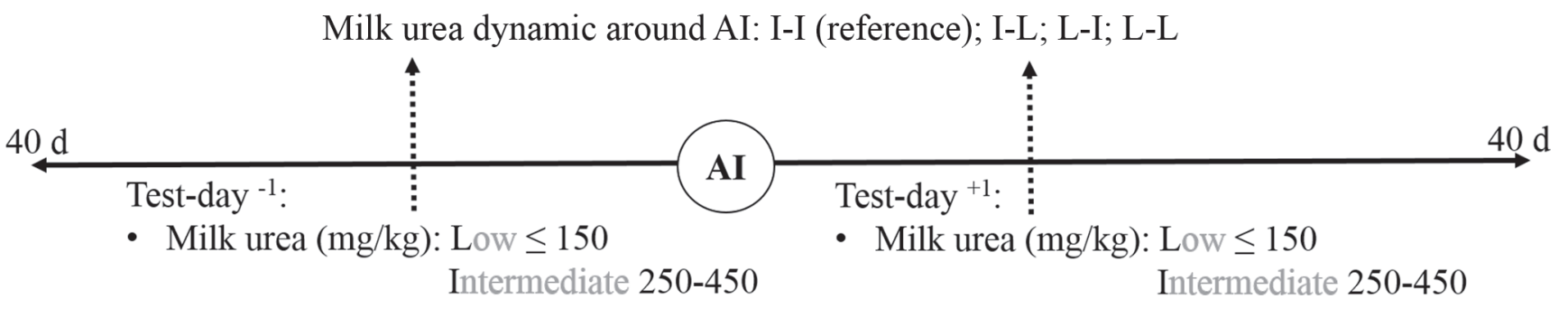

- SCK: Fat and Protein $(\mathrm{mg} / \mathrm{kg})$

Figure 1. A schematic representation of the time of the AI and the measurements examined in this study. Milk urea was measured within $40 \mathrm{~d}$ before and after AI and transformed into a categorical variable representing the dynamic of its level around AI. A proxy of subclinical ketosis (SCK) was built using the fat and protein content $(\mathrm{mg} / \mathrm{kg})$ within $40 \mathrm{~d}$ before AI. I-I = intermediate milk urea levels $(250-450 \mathrm{mg} / \mathrm{kg}$ ) before and after AI; I-L = intermediate levels before and low levels $(\leq 150 \mathrm{mg} / \mathrm{kg})$ after AI; L-I = low levels before and intermediate levels after $\mathrm{AI} ; \mathrm{L}-\mathrm{L}=$ low levels before and after AI.

\section{Statistical Analysis}

Data were analyzed using $\mathrm{R}$ (version 2.10.1, 200912-14, The R Foundation for Statistical Computing, Vienna, Austria). A 2-step statistical analysis was performed. The thresholds used to define the categorical variables included in the final logistic regression (milk urea, SCK, DIM, and 305-d MY) were first obtained through generalized additive models (package gam; https://cran.r-project.org/package=gam). Such models allowed us to determine the nature of the relationship between the response and the explanatory variables such that we were not required to assume a parametric relationship (Hastie and Tibshirani, 1990). Conception success for all AI was explained using continuous variables without any a priori assumptions. Herd was kept in all models as a random effect. This inclusion allowed us to identify the most efficient thresholds by which to define the classes of explanatory variables, such as milk urea, DIM at the time of AI, 305-d MY, and fat and protein contents. Separate univariate models were created with all of the above-mentioned explanatory variables, and the multivariate models were built by adding the significant variables $(P<0.05)$ to each model one by one.

The final logistic regression with a Poisson correction was then performed using the nlme package (https:// cran.r-project.org/package $=$ nlme). A log-link model

Table 1. Descriptive characteristics of the data set for the 4-yr study (2009-2012) and a statistical summary of some variables of interest for cows used in this work

\begin{tabular}{|c|c|c|c|c|}
\hline Item & \multicolumn{4}{|c|}{ Year } \\
\hline Holstein & 446,011 & 464,906 & 509,641 & 464,688 \\
\hline Mean $\mathrm{DIM}^{1} \pm \mathrm{SD}(\mathrm{d})$ & $143.1 \pm 82.0$ & $146.5 \pm 86.8$ & $149.2 \pm 87.7$ & $150.0 \pm 87.9$ \\
\hline Mean \pm SD of $305-\mathrm{d} \mathrm{MY}^{2}(\mathrm{~kg})$ & $8,312 \pm 1,732$ & $8,500 \pm 1,712$ & $8,756 \pm 1,765$ & $8,660 \pm 1,789$ \\
\hline First AI (no.) & 541,522 & 568,148 & 569,989 & 498,109 \\
\hline Success rate $(\%)$ & 39.6 & 40.2 & 38.7 & 41.5 \\
\hline \multicolumn{5}{|l|}{ Milk urea } \\
\hline Mean \pm SD (mg/kg) & $247.4 \pm 89.0$ & $245.8 \pm 91.9$ & $261.2 \pm 91.3$ & $268.2 \pm 86.6$ \\
\hline Median $(\mathrm{mg} / \mathrm{kg})$ & 240 & 250 & 259 & 265 \\
\hline 1st percentile & 60 & 60 & 70 & 85 \\
\hline 99th percentile & 480 & 490 & 502 & 494 \\
\hline
\end{tabular}

${ }^{1}$ At the time of AI.

${ }^{2}$ Milk yield adjusted to a reference lactation period of $305 \mathrm{~d}$. 
with a Poisson distribution was used to calculate relative risks rather than odds ratios and to simultaneously address the lack of convergence sometimes observed in log binomial regressions (Greenland, 2004; Zou, 2004; Ospina et al., 2012). This final model included milk urea as a categorical variable and SCK as a binary variable, with a term of interaction between them, and was adjusted by lactation stage, milk yield, and parity. The logistic model included herd as a random variable and was applied yearly, first for Holstein cows only and then for cows of all breeds (Montbéliarde and Normande added).

\section{RESULTS}

The yearly mean milk urea concentrations ranged between 245.8 and $268.2 \mathrm{mg} / \mathrm{kg}$ (Table 1 ). The results of the generalized additive model showed high consistency between years for the shape of the relationship between conception success and milk urea concentrations before and after AI (Figure 2). A negative linear association between urea levels before AI and conception was observed. However, decreased conception success was observed in association with both low and high levels of milk urea after AI compared with average values. Values of 150 and $250 \mathrm{mg} / \mathrm{kg}(2.6$ and $4.3 \mathrm{mM}$ ) were used as thresholds to distinguish low from intermediate urea levels. The generalized additive model also revealed the shape of the relationship between milk fat and protein content before AI and conception success (Supplemental Figure S1; https://doi.org/10.3168/ jds.2016-12080). The explanatory variables enter the model as nonparametrically smoothed functions, and the obtained smooth curve resembled a step function. The smoothed lines suggest that AI are more successful when fat content ranges between 30 and $40 \mathrm{mg} / \mathrm{kg}$, and then AI success decreases continuously and more sharply after a threshold of $45 \mathrm{mg} / \mathrm{kg}$. In addition, protein contents between 28 and $35 \mathrm{mg} / \mathrm{kg}$ seem to be the most efficient for conception success.

First, the association between conception and urea was analyzed separately for urea levels before and after AI. The models were adjusted using the SCK proxy, DIM, 305-d MY, and parity, with herd as a random variable. The relative risks of conception were not significantly different for low urea $(\leq 150 \mathrm{mg} / \mathrm{kg})$ or intermediate levels (250-450 mg/kg) before AI (Table 2), but conception success was associated with low urea $(\leq 150$ $\mathrm{mg} / \mathrm{kg}$ ) after AI (Table 3); the decrease in conception in cows with low urea after AI was small (3 to $6 \%$ ) but highly significant. A change in milk fat and protein (SCK proxy) was associated with a 16 to $20 \%$ decrease in conception rates. The interaction urea $\times$ SCK proxy was never significant and was excluded from the analyses. Artificial insemination was more successful when it was performed between 50 and 100 DIM compared with attempts outside this period. Within the Holstein breed, highly productive cows had an increased likelihood of conception compared with other cows, as did primiparous compared with multiparous cows (Tables 2 to 4 ). Across all breeds, highly productive cows were less likely to conceive (Supplemental Tables S1, S2, and S3; https://doi.org/10.3168/jds.2016-12080), but primiparous cows were still more likely to conceive. No differences in the results were observed when only first $\mathrm{AI}$ or all AI were included.

Second, conception success and change in urea levels between before and after AI were analyzed with adjustment by SCK proxy, DIM, 305-d MY, and parity, with herd as a random variable (Table 4). An increase in urea from values $\leq 150 \mathrm{mg} / \mathrm{kg}$ before AI to values of 250 to $450 \mathrm{mg} / \mathrm{kg}$ after AI (L-I group) was not associated with changes in conception success compared with the reference group. The opposite change; that is, a decrease in urea from 250 to 450 before AI to $\leq 150$ $\mathrm{mg} / \mathrm{kg}$ after AI (I-L group), was associated with a 5 to $9 \%$ decrease in conception success compared with cows with intermediate urea values $(250-450 \mathrm{mg} / \mathrm{kg})$ before and after AI (I-I group). No interaction was significant. Similar results were obtained when models were run for Holsteins only (Table 4) and for all breeds together (Supplemental Table S3; https://doi.org/10.3168/ jds.2016-12080). In addition, cows of all breeds with low $(\leq 150 \mathrm{mg} / \mathrm{kg})$ milk urea levels before and after AI (L-L group) showed a 2 to $4 \%$ decrease in conception success compared with cows with urea values of 250 to $450 \mathrm{mg} / \mathrm{kg}$ before and after AI (I-I or reference group, Supplemental Table S3). This association was not significant when the model was applied to Holsteins only (Table 4). No differences in the results were observed when only the first AI or all AI attempts were included.

\section{DISCUSSION}

This work found a negative association between low urea and conception only for the period after AI, not for the period before AI (Table 2). Most previous studies analyzing the association between high urea levels and conception found a negative effect of high concentrations at or only after AI (Butler et al., 1996; Melendez et al., 2000), although some conflicting results have been reported. This result shows that the lack of effect of urea level before AI on conception success is also true for low levels of urea. Our results clearly show that low urea levels after AI are a risk factor for conception failure, as described for high levels after AI. This 
finding is in accordance with the trend toward reduced pregnancy rates for cows with milk urea concentrations $<4.0 \mathrm{mM}(233 \mathrm{mg} / \mathrm{kg}$; Pehrson et al., 1992). The effect size reported in this work is limited, with an average $5 \%$ decrease in conception rates for low urea levels compared with intermediate urea levels after AI. This effect size is smaller than the previously reported average 5 to $40 \%$ decrease in conception associated with high urea levels after AI compared with moderate urea levels (in spite of large variations). Although small, the biological relevance of the $5 \%$ decrease in conception for low urea levels after AI remains important, considering

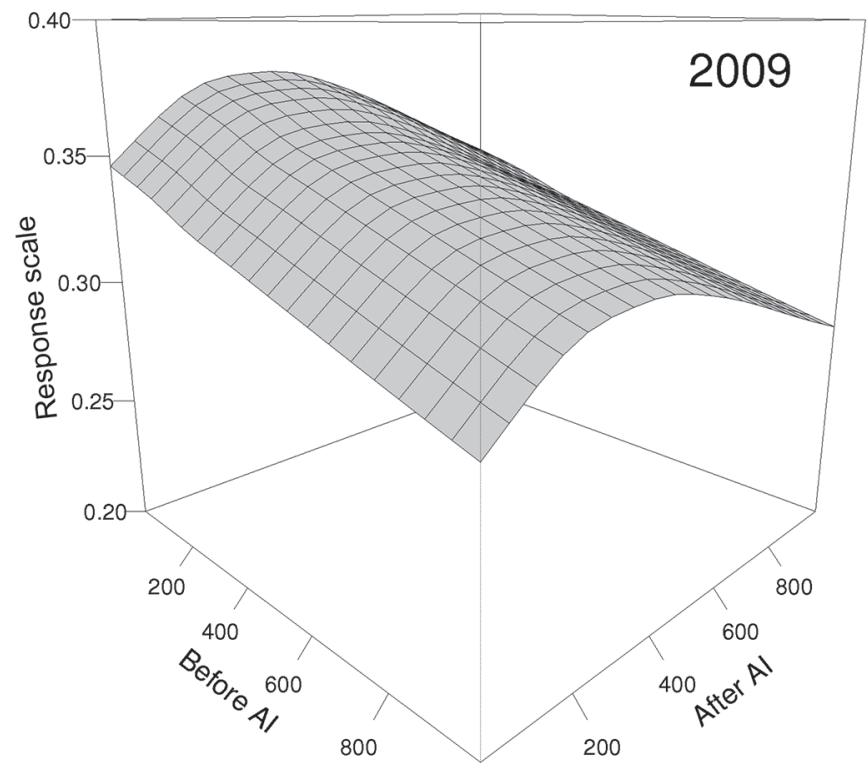

Urea $(\mathrm{mg} / \mathrm{kg})$

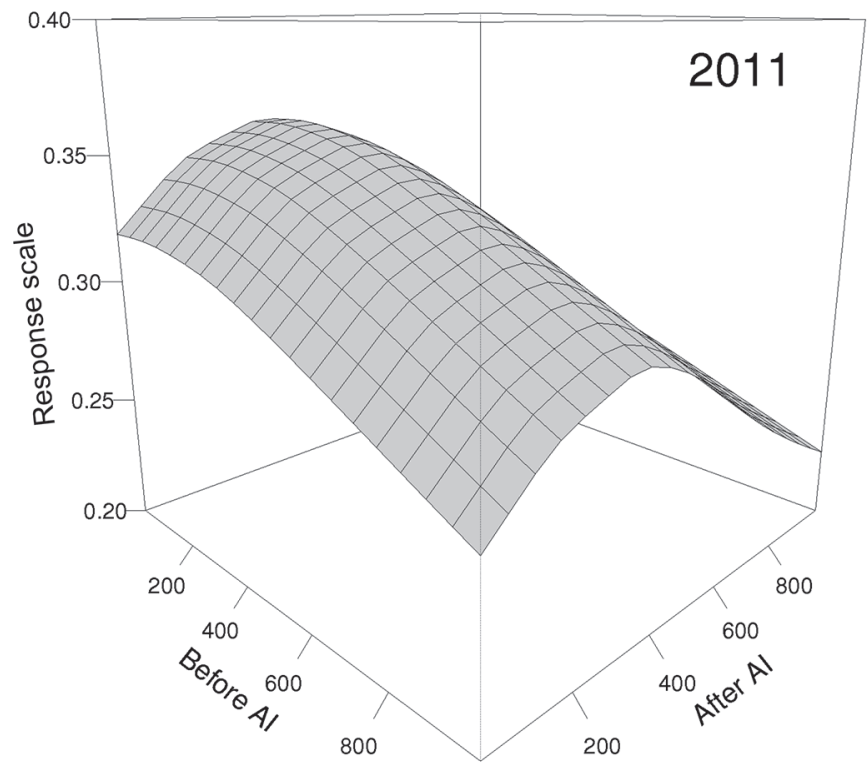

Urea $(\mathrm{mg} / \mathrm{kg})$

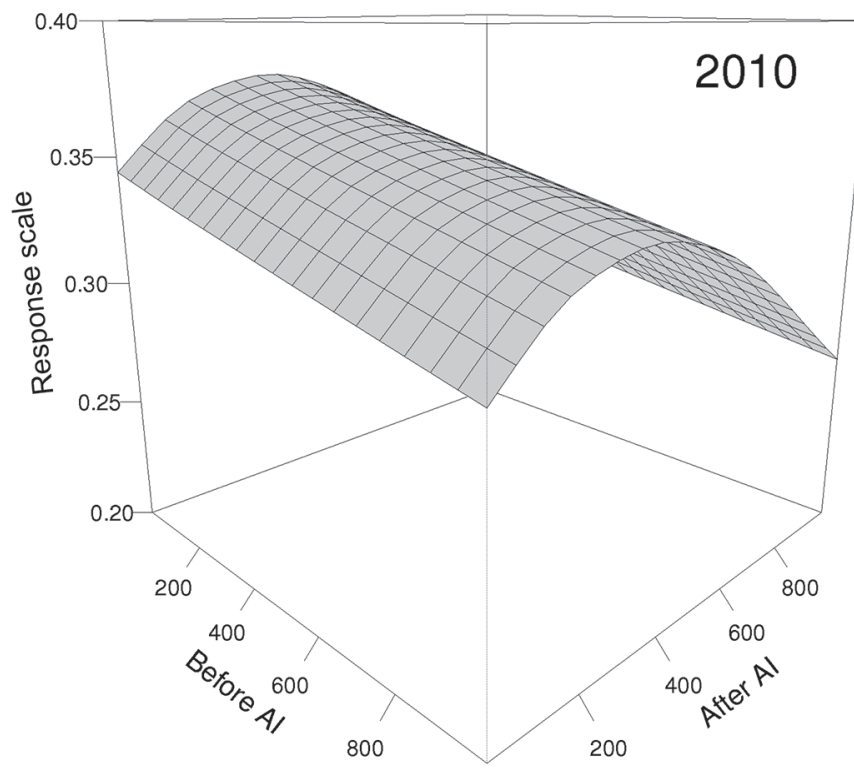

Urea $(\mathrm{mg} / \mathrm{kg})$

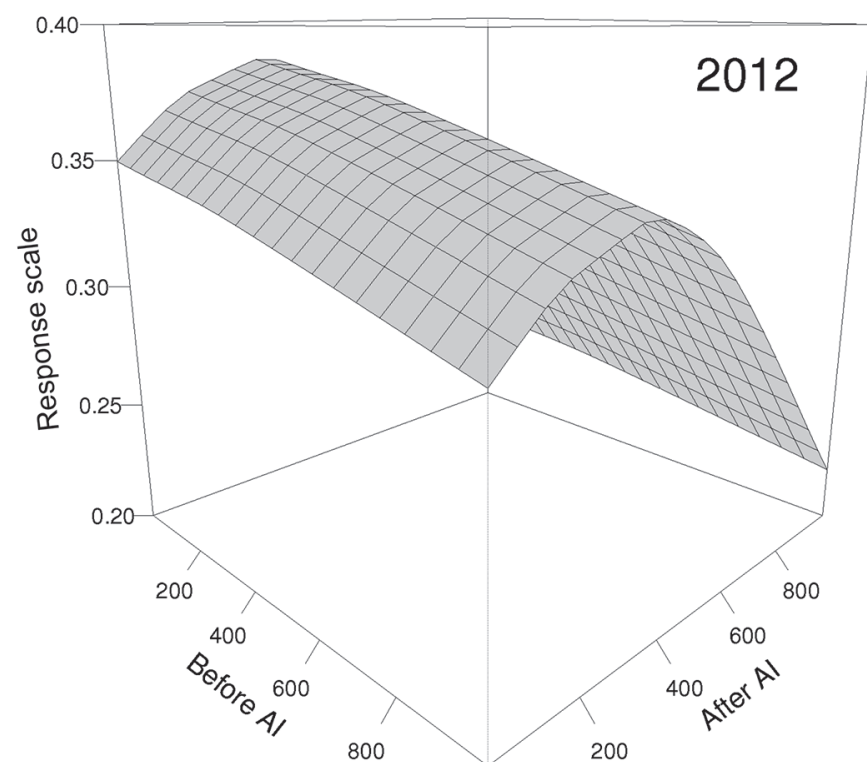

Urea $(\mathrm{mg} / \mathrm{kg})$

Figure 2. A 3-dimensional representation of the annual relationship (from 2009 to 2012) between milk urea levels before and after AI (as smooth functions) and relative values of conception success (response scale) at all AI in Holstein cows. 
Table 2. Relative risk (95\% CI) of conception at all AI associated with the explanatory variables for all years of the study when milk urea was evaluated before AI in Holstein cows

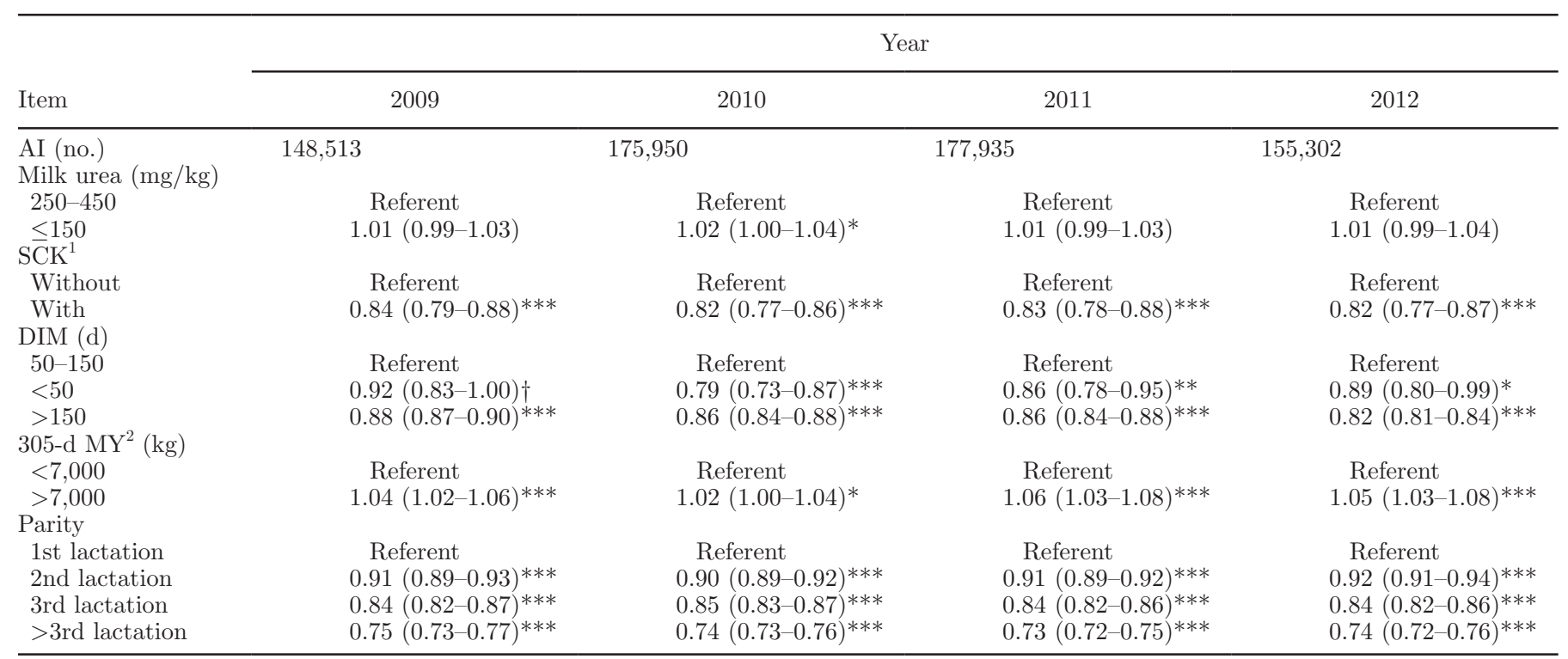

${ }^{1}$ Subclinical ketosis defined as fat content $>45 \mathrm{mg} / \mathrm{kg}$ and protein content $<28 \mathrm{mg} / \mathrm{kg}$ before AI.

${ }^{2}$ Milk yield adjusted to a reference period of $305 \mathrm{~d}$.

*** $P<0.001 ; * * P<0.01 ;{ }^{*} P<0.05 ; \dagger P<0.1$.

the difficulties that farmers face in achieving sufficient reproductive performance and because conception success depends on many factors.

The main result of this work is that cows with intermediate urea levels $(250-450 \mathrm{mg} / \mathrm{kg}$ ) before AI and low urea levels $(\leq 150 \mathrm{mg} / \mathrm{kg}$ ) after AI (I-L group) had a 5 to $9 \%$ reduction in conception compared with cows in the I-I group and that no change in conception success was observed for cows that showed an increase urea levels from low $(\leq 150 \mathrm{mg} / \mathrm{kg})$ before AI to interme-

Table 3. Relative risk (95\% CI) of conception at all AI associated with the explanatory variables for all years of the study when milk urea was evaluated after AI in Holstein cows

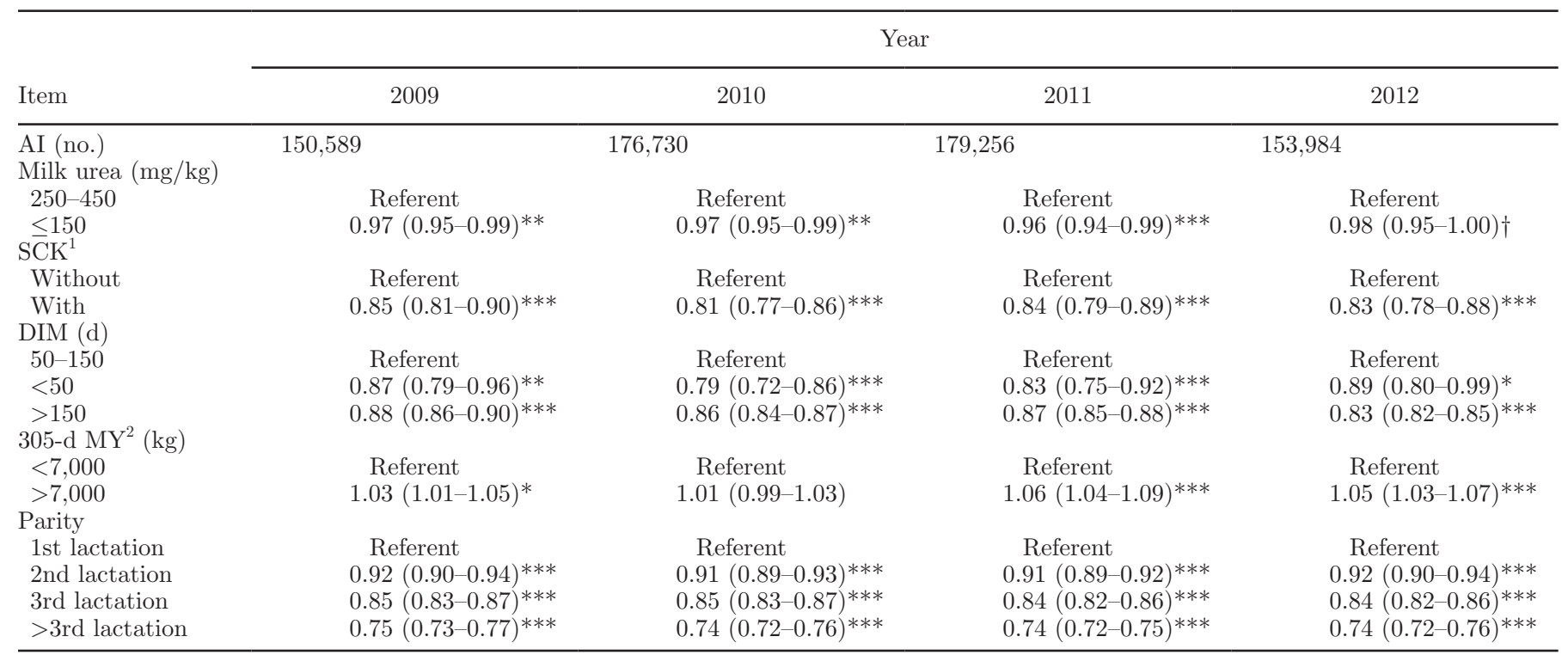

${ }^{1}$ Subclinical ketosis defined as fat content $>45 \mathrm{mg} / \mathrm{kg}$ and protein content $<28 \mathrm{mg} / \mathrm{kg}$ before AI.

${ }^{2}$ Milk yield adjusted to a reference period of $305 \mathrm{~d}$.

*** $P<0.001 ;{ }^{* *} P<0.01 ;{ }^{*} P<0.05 ; \dagger P<0.1$. 
diate after AI (250-450 mg/kg; L-I group) compared with cows in the I-I group. This result reveals that a decrease in urea levels around AI is deleterious for conception and suggests that farmers should consider this type of change in addition to the usual increase from intermediate to high urea levels near the time of AI. This result also confirmed that an increase in urea near the time of AI is only deleterious for conception at high to very high values $(>450 \mathrm{mg} / \mathrm{kg})$ of urea, whereas an increase from low to intermediate values is not a risk factor for conception failure.

A trend was found toward decreased conception in association with low urea levels before and after AI compared with intermediate urea levels before and after conception. This result addresses the increasing tendency toward very low permanent bulk milk urea observed in some herds and suggests that there is no evidence that low urea levels are more beneficial than intermediate urea levels. The negative effect on conception is limited and was only evident for L-L cows from all breeds and not for L-L Holstein cows, although this effect is unexplained.

The mechanisms by which urea concentration may affect reproduction are not clearly defined. They may involve effects on the hypothalamic-pituitary-ovarian axis through alterations to the LH pulse pattern and delays in the time of first ovulation after calving (Eldon et al., 1988) The effect may also be due to lower progesterone production and, consequently, lower conception rates at subsequent inseminations (Folman et al., 1973). In addition, increased urea concentration has been associated with a higher incidence of ovarian cysts (Ropstad and Refsdal, 1987). Other hypotheses suggest that this effect could be due to the potential toxicity of urea in the reproductive tract. Feeding high-CP diets might alter the uterine environment, including its ionic composition (Jordan et al., 1983), and decrease uterine pH (Elrod et al., 1993). Embryonic development was significantly decreased $(18.2 \%)$ in the presence of $6 \mathrm{~m} M$ urea compared with the control group $(23.9 \%)$ when it was evaluated at 7 and $9 \mathrm{~d}$ after start of maturation (De Wit et al., 2001). Oocyte cleavage rates were reduced for a high plasma urea $\mathrm{N}$ group compared with the control group, with subsequent effects on oocyte development to the blastocyst stage, fertilization, and blastocyst quality (Sinclair et al., 2000). In a more recent study, transferring embryos collected $7 \mathrm{~d}$ after insemination from the uteri of lactating

Table 4. Relative risk (95\% CI) of conception at all AI associated with the explanatory variables for all years of the study when milk urea was evaluated through the dynamic of its levels before and after AI in Holstein cows

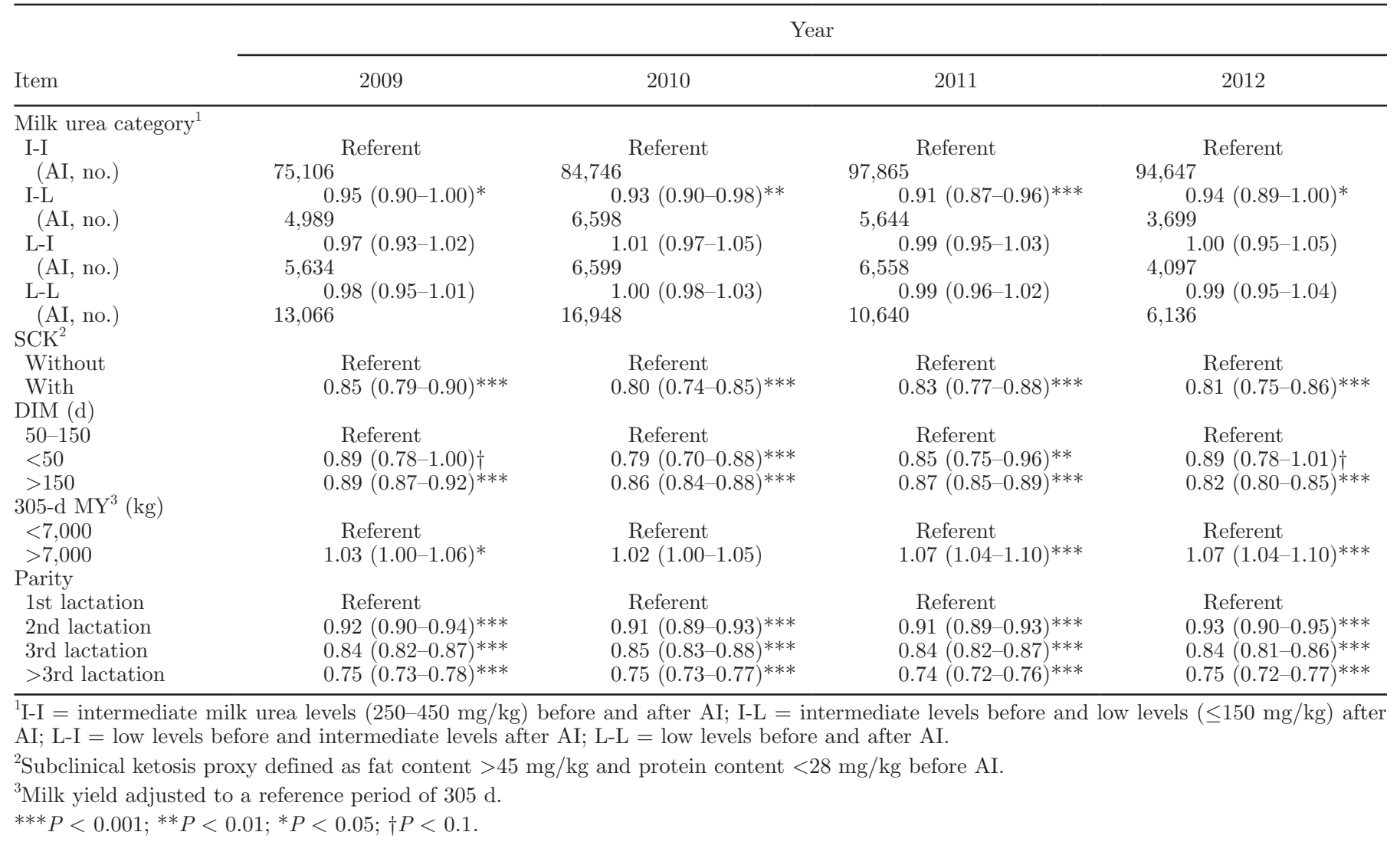


cows with high plasma urea $\mathrm{N}$ concentrations resulted in lower pregnancy rates (11\%) than did transferring embryos collected from cows with moderate plasma urea N levels (35\%; Rhoads et al., 2006). Moreover, mechanisms by which low urea may affect reproduction remain unknown. Low milk urea may reflect inadequate dietary intake of other nutrients, and poor reproductive performance may result from a more severe energy deficit, a reduced $\mathrm{N}$ balance, or from mineral deficiencies (Westwood et al., 1998). In addition, the alteration in the uterus environment including uterine $\mathrm{pH}$ changes and alterations in the uterine secretory activity, as reported for high urea concentrations (Elrod and Butler, 1993), cannot be excluded.

Subclinical ketosis has been reported as a risk factor for deteriorated reproductive performance in dairy cows (Raboisson et al., 2014). In this study, a proxy of SCK was built using the fat and protein contents instead of the consensual definition based on BHB and nonesterified fatty acids. Due to the rapid mobilization of fat after parturition and the reduction in energy supply, SCK is characterized by an increase in milk fat and a decrease in milk protein. Thus, the thresholds of $>45$ and $<28 \mathrm{mg} / \mathrm{kg}$ for milk fat and protein contents, respectively, were suggested as a proxy of SCK. The SCK proxy was associated with a 16 to $20 \%$ decrease in conception rate in this work, in accordance with a previously reported work that used a similar data set (Albaaj et al., 2016). Because of interactions between energy and protein metabolism at the cow level, an interaction between urea and SCK was expected in the current study. The interaction between energy and protein metabolism at early postpartum may arise, in part, from the energy cost for ammonia detoxification (Tamminga, 2006), which could be low or absent when the urea level is low and may partly explain the absence of such interaction in the present work. Further investigations that use shorter time periods and better SCK indicators are needed to more precisely define how energy and protein metabolism interact to affect conception and reproductive performance.

\section{CONCLUSIONS}

This work examined the association between milk urea concentrations and conception success with a focus on low urea levels. Urea levels $\leq 150 \mathrm{mg} / \mathrm{kg}(2.6$ $\mathrm{m} M$ ) were associated with decreased conception success. This association was observed only for urea level after AI, not for that before AI. A decrease in urea levels from intermediate before AI to low after AI was associated with reduced conception success, whereas an increase or a constant low level around AI seemed to be tolerable by cows. This work highlights the interest in monitoring urea as a tool to optimize reproductive performance. Previous works highlighted the negative effects of high urea concentrations on fertility. The present results suggest that low or instable urea levels may also negatively affect reproductive performance in cattle.

\section{ACKNOWLEDGMENTS}

This work was supported by grants from the RUMINFLAME project, as part of the INRA MetaProgramme Gestion Intégrée de la Santé Animale (INRA, Paris, France). We gratefully acknowledge France Génétique Elevage (Paris), France Conseil Elevage (Paris), and the French Livestock Institute (Paris) for the data they provided.

\section{REFERENCES}

Albaaj, A., D. Raboisson, and G. Foucras. 2016. Interaction between conception, mastitis and subclinical ketosis in dairy cows. Page 160 in 16th Int. Conf. Production Diseases in Farm Animals. Wageningen Academic Publishers, Wageningen, the Netherlands.

Baker, L. D., J. D. Ferguson, and W. Chalupa. 1995. Responses in urea and true protein of milk to different protein feeding schemes for dairy cows. J. Dairy Sci. 78:2424-2434. https://doi.org/10.3168/ jds.S0022-0302(95)76871-0.

Barton, B. A., H. A. Rosario, G. W. Anderson, B. P. Grindle, and D. J. Carroll. 1996. Effects of dietary crude protein, breed, parity, and health status on the fertility of dairy cows. J. Dairy Sci. 79:22252236. https://doi.org/10.3168/jds.S0022-0302(96)76599-2.

Bauman, D. E., and W. B. Currie. 1980. Partitioning of nutrients during pregnancy and lactation: A review of mechanisms involving homeostasis and homeorhesis. J. Dairy Sci. 63:1514-1529. https:// doi.org/10.3168/jds.S0022-0302(80)83111-0.

Beam, S. W., and W. R. Butler. 1999. Effects of energy balance on follicular development and first ovulation in postpartum dairy cows. J. Reprod. Fertil. Suppl. 54:411-424.

Bell, A. W. 1995. Regulation of organic nutrient metabolism during transition from early to late pregnancy. J. Anim. Sci. 73:28042819.

Butler, W. R. 1998. Review: Effect of protein nutrition on ovarian and uterine physiology in dairy cattle. J. Dairy Sci. 81:2533-2539. https://doi.org/10.3168/jds.S0022-0302(98)70146-8.

Butler, W. R., J. J. Calaman, S. W. Beam, W. R. Butler, J. J. Calaman, and S. W. Beam. 1996. Plasma and milk urea nitrogen in relation to pregnancy rate in lactating dairy cattle. J. Anim. Sci. $74: 858-865$.

Carlsson, J., and B. Pehrson. 1993. The relationships between seasonal variations in the concentration of urea in bulk milk and the production and fertility of dairy herds. Zentralbl. Veterinarmed. A $40: 205-212$

Carlsson, J., and B. Pehrson. 1994. The influence of the dietary balance between energy and protein on milk urea concentration. Experimental trials assessed by two different protein evaluation systems. Acta Vet. Scand. 35:193-205.

Chaveiro, A. E., M. Andrade, A. E. S. de Borba, and J. F. M. da Silva. 2011. Association between plasma and milk urea on the insemination day and pregnancy rate in early lactation dairy cows. J. Physiol. Pharmacol. Adv. 1:9-14.

Dawuda, P. M., R. J. Scaramuzzi, H. J. Leese, C. J. Hall, A. R. Peters, S. B. Drew, and D. C. Wathes. 2002. Effect of timing of urea feeding on the yield and quality of embryos in lactating dairy cows. Theriogenology 58:1443-1455. https://doi.org/10.1016/S0093691X(02)00973-1. 
De Wit, A. A. C., M. L. F. Cesar, and T. A. M. Kruip. 2001. Effect of urea during in vitro maturation on nuclear maturation and embryo development of bovine cumulus-oocyte-complexes. J. Dairy Sci. 84:1800-1804. https://doi.org/10.3168/jds.S0022-0302(01)746188.

Duffield, T. F., D. F. Kelton, K. E. Leslie, K. D. Lissemore, and J. H. Lumsden. 1997. Use of test day milk fat and milk protein to detect subclinical ketosis in dairy cattle in Ontario. Can. Vet. J. 38:713-718.

Eldon, J., T. H. Thorsteinsson, and T. H. Olafsson. 1988. The concentration of blood glucose, urea, calcium and magnesium in milking dairy cows. Zentralbl. Veterinarmed. A 35:44-53.

Elrod, C. C., and W. R. Butler. 1993. Reduction of fertility and alteration of uterine $\mathrm{pH}$ in heifers fed excess ruminally degradable protein. J. Anim. Sci. 71:694-701.

Elrod, C. C., M. Van Amburgh, and W. R. Butler. 1993. Alterations of $\mathrm{pH}$ in response to increased dietary protein in cattle are unique to the uterus. J. Anim. Sci. 71:702-706.

Folman, Y., M. Rosenberg, Z. Herz, and M. Davidson. 1973. The relationship between plasma progesterone concentration and conception in post-partum dairy cows maintained on two levels of nutrition. J. Reprod. Fertil. 34:267-278. https://doi.org/10.1530/ jrf.0.0340267.

Godden, S. M., D. F. Kelton, K. D. Lissemore, J. S. Walton, K. E. Leslie, and J. H. Lumsden. 2001. Milk urea testing as a tool to monitor reproductive performance in Ontario dairy herds. J. Dairy Sci. 84:1397-1406. https://doi.org/10.3168/jds.S0022-0302(01)701713.

Greenland, S. 2004. Model-based estimation of relative risks and other epidemiologic measures in studies of common outcomes and in case-control studies. Am. J. Epidemiol. 160:301-305. http:// dx.doi.org/https://doi.org/10.1093/aje/kwh221.

Gustafsson, A. H., and J. Carlsson. 1993. Effects of silage quality, protein evaluation systems and milk urea content on milk yield and reproduction in dairy cows. Livest. Prod. Sci. 37:91-105.

Hastie, T. J., and R. Tibshirani. 1990. Generalized additive models. Stat. Sci. 1:297-318. https://doi.org/10.1016/j.csda.2010.05.004.

Heuer, C., W. M. Van Straalen, Y. H. Schukken, A. Dirkzwager, and J. Noordhuizen. 2001. Prediction of energy balance in high yielding dairy cows with test-day information. J. Dairy Sci. 84:471-481.

Jordan, E. R., T. E. Chapman, D. W. Holtan, and L. V. Swanson. 1983. Relationship of dietary crude protein to composition of uterine secretions and blood in high-producing postpartum dairy cows. J. Dairy Sci. 66:1854-1862. https://doi.org/10.3168/jds.S00220302(83)82023-2.

Kenny, D. A., P. G. Humpherson, H. J. Leese, D. G. Morris, A. D. Tomos, M. G. Diskin, and J. M. Sreenan. 2002. Effect of elevated systemic concentrations of ammonia and urea on the metabolite and ionic composition of oviductal fluid in cattle. Biol. Reprod. 66:1797-1804. https://doi.org/10.1095/biolreprod66.6.1797.

Kirchgessner, M., B. R. Paulicks, and F. J. Schwarz. 1988. Veränderungen im Harnstoffgehalt der Kuhmilch bei unzureichender und überhöhter Protein vers orgung. J. Anim. Physiol. Anim. Nutr. (Berl.) 59:79-84. https://doi.org/10.1111/j.1439-0396.1988. tb00050.x.
Laven, R. A., P. M. Dawuda, R. J. Scaramuzzi, D. C. Wathes, H. J. Biggadike, and A. R. Peters. 2004. The effect of feeding diets high in quickly degradable nitrogen on follicular development and embryo growth in lactating Holstein dairy cows. Anim. Reprod. Sci. 84:41-52. https://doi.org/10.1016/j.anireprosci.2003.12.008.

Melendez, P., A. Donovan, and J. Hernandez. 2000. Milk urea nitrogen and infertility in Florida Holstein cows. J. Dairy Sci. 83:459-463. https://doi.org/10.3168/jds.S0022-0302(00)74903-4.

Miettinen, P. V. 1991. Correlation between energy balance and fertility in Finnish dairy cows. Acta Vet. Scand. 32:189-196.

Oltner, R., and H. Wiktorsson. 1983. Urea concentrations in milk and blood as influenced by feeding varying amounts of protein and energy to dairy cows. Livest. Prod. Sci. 10:457-467. https://doi. org/10.1016/0301-6226(83)90073-8

Ospina, P. A., D. V. Nydam, and T. J. DiCiccio. 2012. Technical note: The risk ratio, an alternative to the odds ratio for estimating the association between multiple risk factors and a dichotomous outcome. J. Dairy Sci. 95:2576-2584. https://doi.org/10.3168/ jds.2011-4515.

Pehrson, B., K. Plym Forshell, and J. Carlsson. 1992. The effect of additional feeding on the fertility of high-yielding dairy cows. Zentralbl. Veterinarmed. A 39:187-192.

Raboisson, D., M. Mounié, and E. Maigné. 2014. Diseases, reproductive performance, and changes in milk production associated with subclinical ketosis in dairy cows: A meta-analysis and review. J. Dairy Sci. 97:7547-7563. https://doi.org/10.3168/jds.2014-8237.

Refsdal, A. O., L. Baevre, and R. Bruflot. 1985. Urea concentration in bulk milk as an indicator of the protein supply at the herd level. Acta Vet. Scand. 26:153-163.

Rhoads, M. L., R. P. Rhoads, R. O. Gilbert, R. Toole, and W. R. Butler. 2006. Detrimental effects of high plasma urea nitrogen levels on viability of embryos from lactating dairy cows. Anim. Reprod. Sci. 91:1-10. https://doi.org/10.1016/j.anireprosci.2005.02.009

Ropstad, E., and A. O. Refsdal. 1987. Herd reproductive performance related to urea concentration in bulk milk. Acta Vet. Scand. 28:5563.

Sinclair, K. D., M. Kuran, F. E. Gebbie, R. Webb, and T. G. McEvoy. 2000. Nitrogen metabolism and fertility in cattle: II. Development of oocytes recovered from heifers offered diets differing in their rate of nitrogen release in the rumen. J. Anim. Sci. 78:2670-2680.

Tamminga, S. 2006. The effect of the supply of rumen degradable protein and metabolisable protein on negative energy balance and fertility in dairy cows. Anim. Reprod. Sci. 96:227-239. https://doi. org/10.1016/j.anireprosci.2006.08.003.

Wathes, D. C., V. J. Taylor, Z. Cheng, and G. E. Mann. 2003. Follicle growth, corpus luteum function and their effects on embryo development in postpartum dairy cows. Reprod. Suppl. 61:219-237.

Westwood, C. T., I. J. Lean, and R. C. Kellaway. 1998. Indications and implications for testing of milk urea in dairy cattle: A quantitative review. Part 2. Effect of dietary protein on reproductive performance. N. Z. Vet. J. 46:123-130. https://doi.org/10.1080/0 0480169.1998.36076.

Zou, G. 2004. A modified Poisson regression approach to prospective studies with binary data. Am. J. Epidemiol. 159:702-706. https:// doi.org/10.1093/aje/kwh090. 